\title{
Regulation of Taurine Transport by Escherichia coli Heat-stable Enterotoxin and Guanylin in Human Intestinal Cell Lines
}

\author{
Matthias Brandsch, Sammanda Ramamoorthy, Nandor Marczin, * John D. Catravas, ^ James W. Leibach, \\ Vadivel Ganapathy, and Frederick H. Leibach \\ Departments of Biochemistry and Molecular Biology and * Pharmacology and Toxicology, Medical College of Georgia, \\ Augusta, Georgia 30912-2100
}

\begin{abstract}
The human colon carcinoma cell lines Caco-2 and HT-29 take up taurine actively. Treatment of Caco-2 cells with Escherichia coli heat-stable enterotoxin $\left(\mathrm{ST}_{\mathrm{a}}\right)$ or with guanylin inhibited taurine uptake by $\sim \mathbf{4 0 \%}$. In contrast, neither ST $_{\mathbf{a}}$ nor guanylin changed the uptake of taurine in HT29 cells. The inhibition in Caco-2 cells was associated with a decrease in the maximal velocity as well as in the affinity of the transporter. $\mathrm{ST}_{\mathrm{a}}$ caused a 21 -fold increase in guanosine $3^{\prime}, 5^{\prime}$-cyclic monophosphate (cGMP) levels in Caco-2 cells with no change in cAMP levels. Neither cGMP nor cAMP levels were affected by $\mathrm{ST}_{\mathrm{a}}$ treatment in HT-29 cells. Experiments with protein kinase inhibitors suggested that protein kinase $A$ may mediate the observed effects of $\mathbf{S T}_{\mathbf{a}}$ on taurine uptake. In accordance with this suggestion, treatment of Caco-2 cells with cholera toxin, which elevated intracellular cAMP levels, was found to inhibit taurine uptake. The steady state levels of the taurine transporter mRNA transcripts were not altered as a result of $\mathrm{ST}_{\mathrm{a}}$ treatment. Studies with Caco-2 cells grown on permeable filters revealed that $\mathrm{ST}_{\mathrm{a}}$ acts from the apical side. The taurine uptake from the apical side was inhibited by $\mathrm{ST}_{\mathrm{a}}$, but the taurine uptake from the basolateral side remained unaffected. It is suggested that the activity of the intestinal taurine transporter may be regulated by protein kinase $A$ at a posttranslational level and that the intestinal absorption of taurine may be impaired during infection with enterotoxigenic strains of $\boldsymbol{E}$. coli. (J. Clin. Invest. 1995. 96:361-369.) Key words: taurine transport $\cdot$ intestine $\cdot$ colon carcinoma cells - $E$. coli heat-stable enterotoxin $\cdot$ guanylin
\end{abstract}

\section{Introduction}

The heat-stable enterotoxin $\left(\mathrm{ST}_{\mathrm{a}}\right)^{1}$ produced by certain strains of Escherichia coli is an 18- or 19-amino acid peptide which

Address correspondence to Frederick H. Leibach, Ph.D., Department of Biochemistry and Molecular Biology, Medical College of Georgia, Augusta, GA 30912-2100. Phone: 706-721-7661; FAX: 706-721-6608. Received for publication 19 April 1994 and accepted in revised form 6 March 1995.

1. Abbreviations used in this paper: 8-Br-cGMP, 8-bromo cyclic GMP; cGMP, guanosine 3'5'-cyclic monophosphate; db-cGMP, dibutyryl cyclic GMP; H-89, $N$-[2-( $p$-bromocinnamylamino)ethyl]-5-isoquinoline sulfonamide; IBMX, 3-isobutyl-1-methylxanthine; $\mathrm{ST}_{\mathrm{a}}$, Escherichia coli heat-stable enterotoxin.

J. Clin. Invest.

(C) The American Society for Clinical Investigation, Inc. 0021-9738/95/07/0361/09 \$2.00

Volume 96 , July $1995,361-369$ induces rapid water and electrolyte secretion in the intestine. It is one of the most frequent diarrheagenic agents, particularly in infants and travelers $(1,2)$. The mechanism of $\mathrm{ST}_{\mathrm{a}}$ action on intestinal fluid balance has been investigated in recent years but is not yet fully understood. $\mathrm{ST}_{\mathrm{a}}$ binds to specific receptors in the intestinal brush border membrane (3-5) and activates guanylate cyclase (6). The intestinal membrane-bound guanylate cyclase which is activated by the toxin has itself been shown to be the receptor for the toxin $(7,8)$. Activation of guanylate cyclase by $\mathrm{ST}_{\mathrm{a}}$ leads to a profound increase in the intracellular levels of guanosine 3 ', $5^{\prime}$-cyclic monophosphate (cGMP) in enterocytes $(5,6,9)$. As a second messenger, cGMP might activate protein kinase $\mathrm{G}$ and/or protein kinase $\mathrm{A}(10-12)$ and affect ion transport mechanisms. In particular, $\mathrm{ST}_{\mathrm{a}}$ inhibits $\mathrm{Na}^{+}$ and $\mathrm{Cl}^{-}$absorption and stimulates $\mathrm{Cl}^{-}$secretion in the intestine $(6,9,10,13)$. This cascade is considered as the likely pathway by which $\mathrm{ST}_{\mathrm{a}}$ impairs the intestinal fluid balance in vitro and in vivo $(6,9-14)$. Interestingly, it has been found that $\mathrm{ST}_{\mathrm{a}}$ mimics naturally occurring, endogenous activators of the intestinal guanylate cyclase. The first identified physiological ligand for the " $S \mathrm{~T}_{\mathrm{a}}$-receptor" was the 15-amino acid peptide guanylin (15). Guanylin has been shown to displace $\mathrm{ST}_{\mathrm{a}}$ from its binding sites, activate guanylate cyclase $(15-18)$ and stimulate $\mathrm{Cl}^{-}$ secretion in human intestinal cells (19). Guanylin appears to be less potent than $\mathrm{ST}_{\mathrm{a}}$. However, a more potent member of this peptide family, uroguanylin, which might be a regulatory signal for ion transport in renal tissue, has been recently identified (20).

Until now, studies on the pathophysiological role of cGMP in intestinal function have been mostly focused on the influence of this cyclic nucleotide on ion transport. There is very little information available on the role of cGMP in the intestinal absorption of nutrients other than electrolytes. The present study was undertaken to investigate the effects of $\mathrm{ST}_{\mathrm{a}}$ and guanylin, and thereby of cGMP, on the intestinal absorption of a unique amino acid, taurine. Though this amino acid is not incorporated into proteins and is known to participate in only very few metabolic reactions, it is the most abundant free amino acid in many tissues. Available evidence indicates that taurine might participate in a variety of cellular functions (21) and even be an essential nutrient during development (22). The nutritional needs for this amino acid in man and in animals are met mainly by intestinal absorption from dietary sources. Absorption of taurine in the intestine occurs via a transport system that is specific for taurine and other $\beta$-amino acids (23). The characteristics of the taurine transporter expressed in the intestinal brush border membrane have been studied in detail (24-28). Recently, the human colon carcinoma cell lines HT-29 and Caco-2 have been shown to express the taurine transporter (29, 30 ). These cell lines have become very useful to investigate the regulatory aspects of various intestinal transport systems. Using these cell lines as a model system, we have shown that 
the activity of the taurine transporter is regulated by protein kinase $C(30)$. In the present investigation, we have used these cell lines to study the influence of $\mathrm{ST}_{\mathrm{a}}$ and guanylin on the activity of the intestinal taurine transporter. The results of this investigation reveal that $\mathrm{ST}_{\mathrm{a}}$ and guanylin increase intracellular levels of cGMP in Caco-2 cells but not in HT-29 cells and that the elevation of cGMP levels in Caco-2 cells is associated with a significant decrease in the activity of the taurine transporter.

\section{Methods}

Cell culture. Caco-2 cells were routinely cultured in $75-\mathrm{cm}^{2}$ collagentreated (calf skin collagen type I, $5 \mu \mathrm{g} / \mathrm{cm}^{2}$ ) culture flasks with MEM supplemented with $10 \%$ FBS, penicillin $(100 \mathrm{U} / \mathrm{ml})$, streptomycin ( 100 $\mu \mathrm{g} / \mathrm{ml}$ ), and $1 \%$ nonessential amino acid solution. The cells were maintained at $37^{\circ} \mathrm{C}$ and $5 \% \mathrm{CO}_{2}$. Subconfluent cultures were treated with PBS containing $0.25 \%$ trypsin and $0.5 \mathrm{mM}$ EDTA. Subcultures were started from the released and washed cells. For most experiments, the cells were seeded in $35-\mathrm{mm}$ disposable collagen-treated $\left(4 \mu \mathrm{g} / \mathrm{cm}^{2}\right)$ petri dishes at a density of $1 \times 10^{6}$ cells per dish and allowed to grow to confluence. The culture medium was changed every other day. The uptake measurements were performed using confluent monolayers on the 4 th or 5 th day after seeding. In some experiments cells were cultured for up to $10 \mathrm{~d}$.

Caco-2 cells were also cultured on permeable polycarbonate Transwell $^{\mathrm{TM}}$ cell culture inserts with some modifications similar to the procedure described by Hidalgo et al. (31). Cells were cultured in 75$\mathrm{cm}^{2}$ non-collagen-treated culture flasks in complete MEM. Subconfluent cultures were treated 10 min with PBS containing $0.5 \mathrm{mM}$ EDTA followed by a 10 -s incubation with $0.25 \%$ trypsin and $1 \mathrm{mM}$ EDTA. Subcultures were started from the released cells on rat tail collagencoated $\left(77 \mu \mathrm{g} / \mathrm{cm}^{2}\right)$ Transwell ${ }^{\mathrm{TM}}$ cell culture inserts at a cell density of 82,000 cells $/ \mathrm{cm}^{2}$ and cultured for up to $17 \mathrm{~d}$. The culture medium was changed every other day. The lower (basolateral) compartment contained $2.6 \mathrm{ml}$ medium and the upper (apical) compartment $1.5 \mathrm{ml}$ medium. The transepithelial resistance was routinely measured using a Millicell Electrical Resistance System (Millipore Corp., Bedford, MA).

HT-29 cells were also routinely cultured in a similar way, with some modifications. Trypsin treatment of cells grown in untreated culture flasks was done with PBS containing 0.1\% trypsin and 0.25 mM EDTA. The culture medium for HT-29 cells was DME supplemented with $10 \%$ FBS, penicillin $(100 \mathrm{U} / \mathrm{ml})$ and streptomycin $(100 \mu \mathrm{g} / \mathrm{ml})$. It contained D-glucose at a concentration of 4.5 grams/liter. Cells were seeded in untreated $35-\mathrm{mm}$ dishes at a density of $1.5 \times 10^{6}$ cells/dish and used for uptake measurements at full confluence on the 4th or 5th day after seeding.

Cell treatments. Stock solutions of compounds were prepared in deionized water or DMSO. Cultured cells were preincubated in the respective media at $37^{\circ} \mathrm{C}$ and $5 \% \mathrm{CO}_{2}$ with desired concentrations of $\mathrm{ST}_{\mathrm{a}}$ (mostly $\left.50 \mathrm{nM}\right)$, guanylin $(5 \mu \mathrm{M})$, cGMP-analogues $(1 \mathrm{mM})$, cholera toxin $(100 \mathrm{ng} / \mathrm{ml})$, or protein kinase inhibitors for desired time periods.

Uptake measurements. Uptake of taurine and other amino acids by Caco-2 cells cultured on plastic dishes was measured at room temperature as described earlier $(30,32,33)$. The uptake buffer contained (mM) 25 Hepes-Tris ( $\mathrm{pH} 7.5$ ), $140 \mathrm{NaCl}, 5.4 \mathrm{KCl}, 1.8 \mathrm{CaCl}_{2}, 0.8$ $\mathrm{MgSO}_{4}, 5$ glucose, and radiolabeled amino acids, glucose or glycylsarcosine (Gly-Sar). In some experiments, $\mathbf{S T}_{\mathbf{a}}$ was also added to the uptake buffer. After incubation for a desired time period, the buffer was removed and the cells were quickly washed four times with ice-cold uptake buffer. $1 \mathrm{ml}$ of $0.2 \mathrm{M} \mathrm{NaOH}$ containing $1 \%$ SDS was added to each dish, and the radioactivity of the contents from the dishes was measured by liquid scintillation spectrometry.

The uptake buffer was modified in some experiments. For the measurement of glucose uptake, the wash and uptake buffers contained glucose at a concentration of $100 \mu \mathrm{M}$ instead of $5 \mathrm{mM}$. To determine the effect of $\mathrm{ST}_{\mathrm{a}}$ on the proton-dependent peptide transport in Caco-2 cells, a pH 6.0 buffer in which Hepes was replaced by Mes was used.
For the measurement of taurine uptake in the absence of sodium or chloride, $\mathrm{KCl}$ and $\mathrm{CaCl}_{2}$ in the uptake buffer were replaced by potassium gluconate and calcium gluconate. The sodium-free buffer was prepared by replacing $\mathrm{NaCl}$ with choline chloride and the chloride-free buffer was prepared by replacing $\mathrm{NaCl}$ with sodium gluconate. The sodiumand chloride-free buffer was prepared by using $N$-methyl-D-glucamine gluconate, potassium gluconate, and calcium gluconate.

Uptake of taurine in Caco-2 cells cultured on permeable filters and treated with or without $\mathrm{ST}_{\mathrm{a}}(200 \mathrm{nM}$ for $1 \mathrm{~h})$ in MEM was measured as follows. The inserts were washed with the $\mathrm{NaCl}$-containing buffer $(\mathrm{pH} 7.5)$ and the uptake was started by adding uptake buffer containing radiolabeled taurine $(60 \mathrm{nM})$ either to the apical $(1.5 \mathrm{ml})$ or to the basolateral $(2.6 \mathrm{ml})$ side of the chamber. After a 10-min incubation time the filters were quickly washed four times with ice-cold uptake buffer, cut out of the plastic insert and transferred to scintillation vials. One $\mathrm{ml}$ of $0.2 \mathrm{M} \mathrm{NaOH}$ containing $1 \% \mathrm{SDS}$ was added and the radioactivity was measured. The inulin flux through Caco- 2 cell monolayer and through filters without cells (blanks) was estimated by adding radiolabeled inulin $(0.3 \mu \mathrm{Ci} / \mathrm{ml})$ to either the apical or the basolateral compartment (donor compartments). At time intervals of 10, 20, 40, and 60 min, $100 \mu \mathrm{l}$ medium was taken from the receiver compartment and replaced with $100 \mu \mathrm{l}$ fresh buffer. The radioactivity in these aliquots was measured. After correction for the amount taken out, these data were converted into flux data in percentage of total radioactivity of the respective donor compartment per hour.

For each experiment, the samples for protein estimation were prepared and measured as described earlier (33).

Assay of cGMP and cAMP. Caco-2 and HT-29 cells were cultured for $4 \mathrm{~d}$. The cGMP- as well as cAMP-levels were measured as previously described (34) in control and $\mathrm{ST}_{\mathrm{a}}$ - or cholera toxin-treated cells. In brief, confluent cell layers were incubated for $15 \mathrm{~min}$ at room temperature in the uptake buffer ( $\mathrm{pH} 7.5$ ) containing $1 \mathrm{mM}$ 3-isobutyl-1-methylxanthine (IBMX) and then exposed to $\mathrm{ST}_{\mathrm{a}}(50 \mathrm{nM})$ for $5 \mathrm{~min}$ or to cholera toxin $(100 \mathrm{ng} / \mathrm{ml})$ for $4 \mathrm{~h}$ in the presence of $1 \mathrm{mM}$ IBMX. After this treatment, the cells were washed once with ice-cold buffer containing $1 \mathrm{mM}$ IBMX. Cells were then lysed by incubating the cell layer in 1 $\mathrm{ml}$ of $0.1 \mathrm{~N} \mathrm{HCl}$ for $30 \mathrm{~min}$. The acid extract was collected and used for measurement of cGMP and cAMP. Radioimmunoassay of these cyclic nucleotides was performed using the Gammaflow automated radioimmunoassay system (Atto Instruments, Inc., Potomac, MD) (34).

mRNA isolation and Northern analysis. Caco-2 cells were cultured in $225-\mathrm{cm}^{2}$ culture flasks for $5 \mathrm{~d}$ to full confluence. Treatment was performed in these flasks in the respective media at $37^{\circ} \mathrm{C}$ and $5 \% \mathrm{CO}_{2}$ with or without $\mathrm{ST}_{\mathrm{a}}(50 \mathrm{nM})$ for $30 \mathrm{~min}$. Following this treatment, the cell layers were washed twice with ice-cold PBS. Poly (A) ${ }^{+}$RNA from these cells was isolated using the FastTrack mRNA isolation kit (Invitrogen, San Diego, CA). Size-fractionation of mRNA and Northern analysis were performed as described (35). A 705-bp fragment of the coding region of the human placental taurine transporter cDNA (36) was used as the probe. Radiolabeling of the probe with $\left[\alpha-{ }^{32} \mathrm{P}\right] \mathrm{dCTP}$ was done by random priming.

Statistics. Each experimental point shown represents the mean \pm SEM of 3 to 12 independent measurements. The kinetic constants were calculated by linear regression of the Eadie-Hofstee plot and confirmed by nonlinear methods. The calculated parameters are shown with their SEM. Statistical analysis of the kinetic parameters comparing independent kinetic experiments was done by the paired Student's $t$ test. Other statistical analyses were done by the two-tailed nonparametric U-test. A $P \leq 0.05$ was considered significant.

Materials. HT-29 and Caco-2 human colon carcinoma cell lines were obtained from the American Type Culture Collection (Rockville, MD). [2- $\left.{ }^{3} \mathrm{H}(\mathrm{n})\right]$ Taurine (specific radioactivity, 21.9 or $30.0 \mathrm{Ci} / \mathrm{mmol}$ ) was obtained from DuPont-New England Nuclear (Boston, MA) or from American Radiolabeled Chemicals Inc. (St. Louis, MO). $\beta-\left[3-{ }^{3} \mathrm{H}(\mathrm{n})\right]-$ Alanine (specific radioactivity, $120 \mathrm{Ci} / \mathrm{mmol}$ ), L- $\left.[4,5]-{ }^{3} \mathrm{H}(\mathrm{n})\right]$ leucine (specific radioactivity, $60.0 \mathrm{Ci} / \mathrm{mmol}$ ), L- $\left[\right.$ ring-2,6- $\left.{ }^{3} \mathrm{H}(\mathrm{n})\right]$ phenylalanine (specific radioactivity, $60.0 \mathrm{Ci} / \mathrm{mmol}$ ), L- $\left[5-{ }^{3} \mathrm{H}\right]$ proline (specific radioactivity, $9.9 \mathrm{Ci} / \mathrm{mmol}$ ), D- $\left[1-{ }^{3} \mathrm{H}\right]$ glucose (specific radioactivity, $15.5 \mathrm{Ci} / \mathrm{mmol})$, hydroxymethyl $\left[{ }^{14} \mathrm{C}\right]$ inulin $(17 \mu \mathrm{Ci} / \mathrm{ml})$, and $\left[\alpha-{ }^{32} \mathrm{P}\right]-$ 

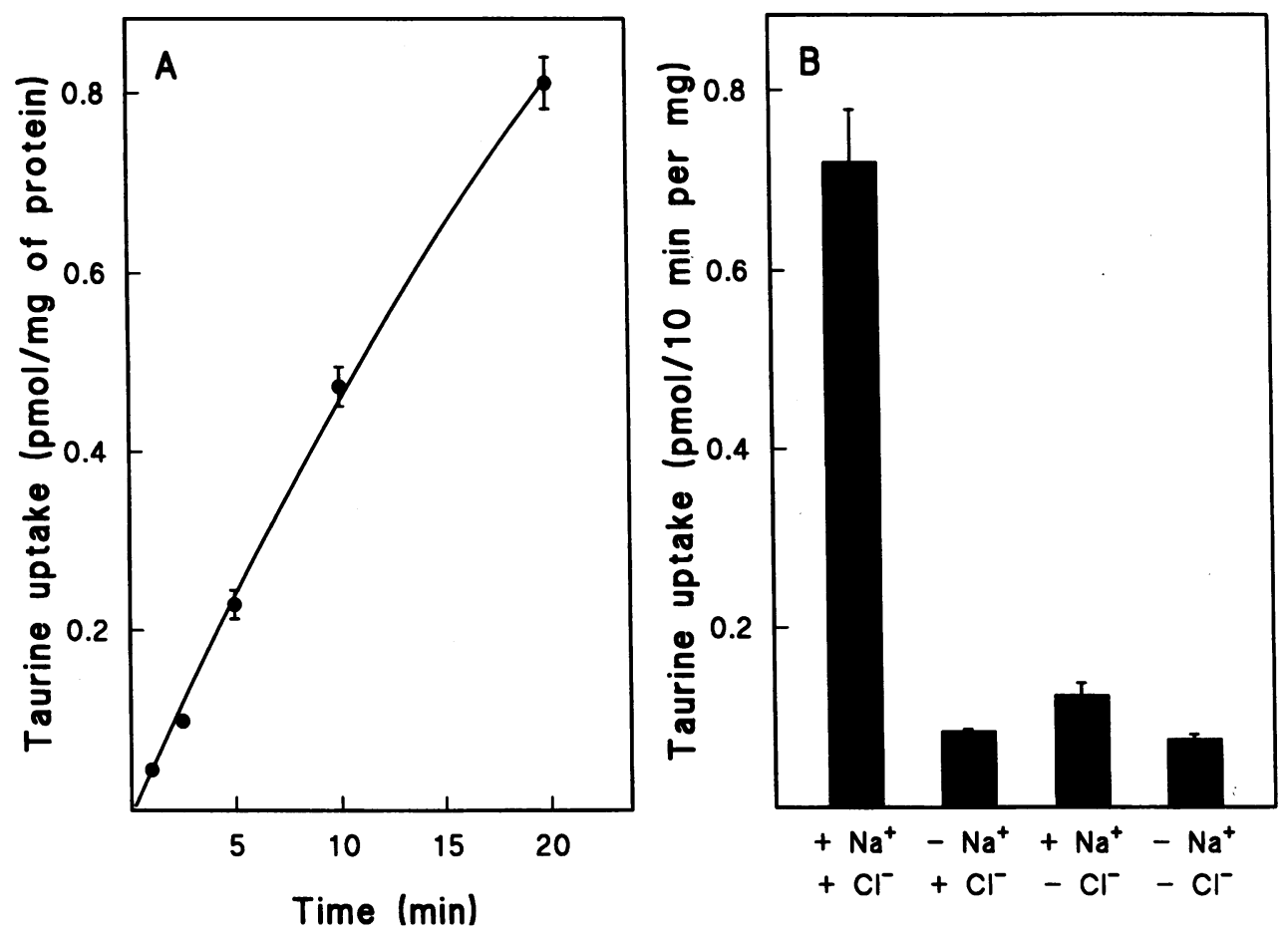

Figure 1. Characteristics of taurine uptake in the Caco-2 cell line. Uptake of taurine was measured in confluent monolayers of Caco2 cells. $(A)$ Time-dependent uptake of taurine $(40 \mathrm{nM})$ measured in a $\mathrm{NaCl}$-containing buffer at $\mathrm{pH}$ 7.5. Values are means \pm SEM $(n=3)$. ( $B)$ Dependence of taurine uptake $(40 \mathrm{nM})$ on $\mathrm{Na}^{+}$and $\mathrm{Cl}^{-}$. Uptake was measured with a 10-min incubation in a buffer $(\mathrm{pH}$ 7.5) that contained $\mathrm{Na}^{+}$and $\mathrm{Cl}^{-}$, $\mathrm{Cl}^{-}$but no $\mathrm{Na}^{+}, \mathrm{Na}^{+}$but no $\mathrm{Cl}^{-}$, or neither $\mathrm{Na}^{+}$nor $\mathrm{Cl}^{-}$. Values are means $\pm \operatorname{SEM}(n=3-7)$.
dCTP (specific radioactivity, $3,000 \mathrm{Ci} / \mathrm{mmol}$ ) were purchased from DuPont-New England Nuclear. $\left[2-{ }^{14} \mathrm{C}\right]$ Glycyl- $\left[1-{ }^{14} \mathrm{C}\right]$ sarcosine (specific radioactivity, $109 \mathrm{mCi} / \mathrm{mmol}$ ) was custom synthesized by Cambridge Research Biochemicals, Ltd. (Cleveland, UK). Unlabeled amino acids, $\mathrm{ST}_{\mathrm{a}}$, cholera toxin, 8-bromo cyclic GMP (8-Br-cGMP), dibutyryl cyclic GMP (db-cGMP), IBMX, staurosporine, and calf skin collagen were from Sigma (St. Louis, MO). Collagen I solution (rat tail) was from Collaborative Biomedical Research (Bedford, MA). DME containing D-glucose and L-glutamine, MEM, nonessential amino acid solution, penicillin $(10,000 \mathrm{U} / \mathrm{ml}) /$ streptomycin $(10,000 \mu \mathrm{g} / \mathrm{ml})$, and Trypsin/EDTA solution were purchased from GIBCO BRL (Gaithersburg, MD). FBS was obtained from Atlanta Biologicals, Inc. (Norcross, GA) and guanylin from Peptide Institute Inc. (Osaka, Japan). The protein kinase inhibitors $N$-[2-(p-bromocinnamylamino)ethyl]-5-isoquinoline sulfonamide (H-89), KT5823, and chelerythrine were obtained from LC Laboratories (Woburn, MA). The 24-mm Transwell ${ }^{\mathrm{TM}}$ porous cell culture inserts (3- $\mu \mathrm{m}$ pore size, polycarbonate membrane) were purchased from Costar (Cambridge, MA).

\section{Results}

Effect of E. coli $S T_{a}$ and guanylin on taurine uptake in HT-29 and Caco-2 cells. We have previously shown that HT-29 cells as well as Caco- 2 cells possess taurine transport activity (29, $30)$. A transport system responsible for taurine uptake has been characterized in HT-29 cells (29). These studies have established that the uptake of taurine in HT-29 cells occurs via a $\mathrm{Na}^{+}$- and $\mathrm{Cl}^{-}$-coupled transporter which is specific for taurine and other $\beta$-amino acids. The taurine uptake system expressed in Caco- 2 cells has not been studied in detail. Fig. 1 describes the time-dependent uptake of taurine and the influence of $\mathrm{Na}^{+}$ and $\mathrm{Cl}^{-}$on the uptake process in Caco-2 cells. The uptake was found to be linear at least up to $10 \mathrm{~min}$. The intracellular concentration of taurine, calculated by using a value of $3.6 \mu \mathrm{l} /$ $\mathrm{mg}$ of protein for the intracellular volume $(37,38)$, was 225 $\mathrm{nM}$ after $20 \mathrm{~min}$ incubation while the concentration of taurine in the extracellular medium was $40 \mathrm{nM}$. These data show that Caco-2 cells are capable of transporting this amino acid against a concentration gradient as has been previously shown for HT29 cells. The uptake of taurine in Caco- 2 cells was found to be dependent on the presence of both $\mathrm{Na}^{+}$and $\mathrm{Cl}^{-}$in the uptake medium. The presence of either $\mathrm{Na}^{+}$or $\mathrm{Cl}^{-}$alone was unable to support taurine uptake. In the absence of both $\mathrm{Na}^{+}$and $\mathrm{Cl}^{-}$ the taurine uptake was similar to that in the absence of $\mathrm{Na}^{+}$. Thus, the uptake of taurine in Caco- 2 cells is mediated by a $\mathrm{Na}^{+}$- and $\mathrm{Cl}^{-}$-coupled transporter. We also performed this experiment at a taurine concentration of $1 \mu \mathrm{M}$ and found that the uptake was obligatorily dependent on $\mathrm{Na}^{+}$and $\mathrm{Cl}^{-}$even under these conditions.

Table I shows the effects of $\mathrm{ST}_{\mathrm{a}}$ and guanylin on taurine uptake in HT-29 and Caco-2 cells. In agreement with the results published earlier (30), the taurine transport activity in HT-29 cells was 4.4 times higher than the taurine transport activity in Caco-2 cells. Interestingly, treatment of the cells with $\mathrm{ST}_{\mathrm{a}}$ and

Table I. Effect of E. coli $S T_{a}$ and Guanylin on Taurine Uptake in HT-29 and Caco-2 cells

\begin{tabular}{lcccr}
\hline & \multicolumn{4}{c}{ Taurine uptake } \\
\cline { 2 - 5 } \multicolumn{1}{c}{ Compound } & HT-29 & \multicolumn{2}{c}{ Caco-2 } \\
& pmoll10 min per mg & $\%$ & pmollo min per $m g$ & $\%$ \\
& & & & \\
Control & $3.76 \pm 0.03$ & 100 & $0.85 \pm 0.04$ & 100 \\
ST $_{\mathrm{a}}(100 \mathrm{nM})$ & $3.85 \pm 0.02$ & 102 & $0.57 \pm 0.09$ & 67 \\
& $(\mathrm{NS})$ & & $(P<0.05)$ & \\
Guanylin $(5 \mu \mathrm{M})$ & $3.70 \pm 0.01$ & 98 & $0.50 \pm 0.09$ & 59 \\
& $(\mathrm{NS})$ & & $(P<0.05)$ & \\
& & & & \\
\hline
\end{tabular}

Values are means $\pm \operatorname{SEM}(n=4)$. After a 1 -h treatment at $37^{\circ} \mathrm{C}$ of monolayer cultures of HT-29 and Caco-2 cells with the compounds shown, uptake of taurine $(40 \mathrm{nM})$ was measured in a $\mathrm{NaCl}$-containing buffer at $\mathrm{pH} 7.5$ using a 10 -min incubation. NS, not significant; $P$ values compared to respective controls. 


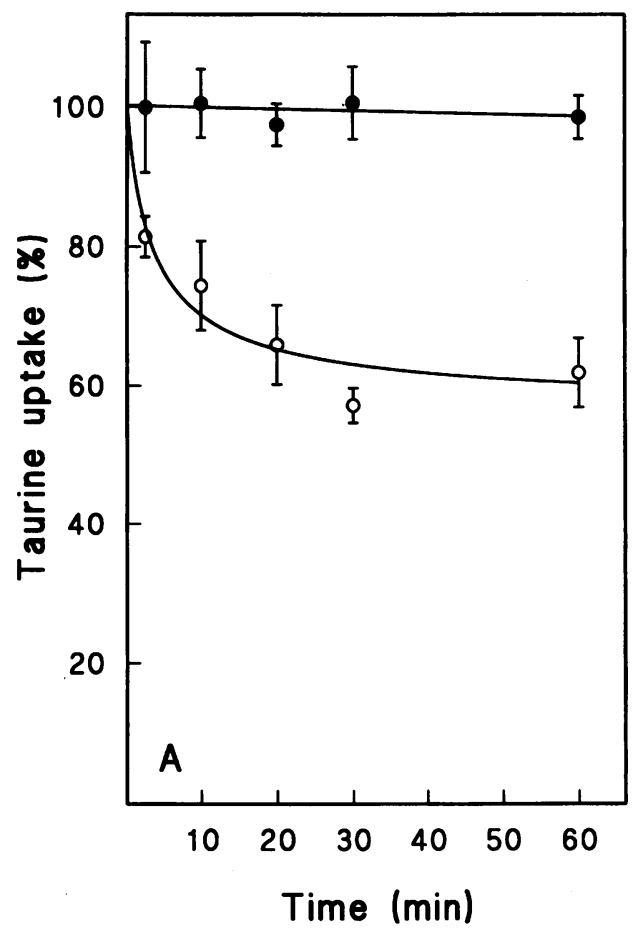

guanylin was found to inhibit taurine uptake only in Caco-2 cells. The uptake of taurine in HT-29 cells remained unaffected by treatment with these agents under identical conditions. With a treatment time of $1 \mathrm{~h}$, the inhibition of taurine uptake observed in Caco-2 cells was $\sim 30 \%$ with $\mathrm{ST}_{\mathrm{a}}(100 \mathrm{nM})$ and $\sim 40 \%$ with guanylin $(5 \mu \mathrm{M})$. In a separate experiment, we determined whether the presence of $\mathrm{ST}_{\mathrm{a}}$ not only during treatment but also during uptake measurement would increase the inhibition of taurine uptake. The presence of $\mathrm{ST}_{\mathrm{a}}$ during treatment alone caused a $39 \%$ inhibition, and this value was not significantly altered $(42 \%)$ when $\mathrm{ST}_{\mathrm{a}}$ was present during treatment and uptake measurement.

In another series of experiments, we studied the effect of culture time (4-10 d) of the cells on the taurine uptake and on the magnitude of the $\mathrm{ST}_{\mathrm{a}}$ effect. The experiments revealed, as already described in a former publication (30), that with increasing number of days after confluence the specific taurine transport activity decreases. In these experiments the taurine transport declined continuously to $67 \%$ at day 10 compared to transport at day 4 . However, treatment with $\mathrm{ST}_{\mathrm{a}}(50 \mathrm{nM}, 30$ min) inhibited the taurine transport by $30-45 \%$ and the rate of inhibition did not correlate with the age of the monolayers.

Influence of treatment time and $S T_{a}$ concentration on taurine uptake in Caco-2 cells. The $\mathrm{ST}_{\mathrm{a}}$-induced inhibition of taurine uptake in Caco- 2 cells was very rapid. Even when the cells had not been treated with the toxin before uptake and the toxin was present in the medium only during the 10-min uptake period, the uptake of taurine was found to be inhibited by $\sim 15 \%$. A similar extent of inhibition was observed when $\mathrm{ST}_{\mathrm{a}}$ was added to the medium and immediately removed before initiating uptake measurement. The influence of treatment time on $\mathrm{ST}_{\mathrm{a}}$-induced inhibition of taurine uptake was therefore studied by incubating the cells with $\mathrm{ST}_{\mathrm{a}}(50 \mathrm{nM})$ for varying periods of time (2.5$60 \mathrm{~min}$ ), followed by removal of the toxin before initiation of uptake measurement (Fig. $2 A$ ). Cells which were treated similarly but in the absence of $\mathrm{ST}_{\mathrm{a}}$ served as controls. The $\mathrm{ST}_{\mathrm{a}}$ - induced inhibition of taurine uptake increased as the treatment time increased and the maximal inhibition $(\sim 40 \%)$ was reached after $30 \mathrm{~min}$ treatment. Extension of treatment time beyond $30 \mathrm{~min}$ ( up to $4 \mathrm{~h}$ ) did not result in any further increase in the inhibition. Subsequent experiments to characterize the $\mathrm{ST}_{\mathrm{a}}$-induced inhibition were performed using a 30-min treatment time. The dose-response relationship for the $\mathrm{ST}_{\mathrm{a}}$-induced inhibition is shown in Fig. $2 B$. Measured over a concentration range of $0.5-320 \mathrm{nM}$, the $\mathrm{ST}_{\mathrm{a}}$-induced inhibition of taurine uptake was evident at a toxin concentration as low as $16 \mathrm{nM}$. The inhibition reached the maximum $(\sim 40 \%)$ at a $\mathrm{ST}_{\mathrm{a}}$ concentration of $50 \mathrm{nM}$. There was no further increase in the extent of inhibition over the toxin concentration range of 50-320 nM. The $\mathrm{IC}_{50}$ value, the concentration of $\mathrm{ST}_{\mathrm{a}}$ necessary to produce $50 \%$ of the maximal inhibitory effect, was $21.2 \pm 2.3 \mathrm{nM}$.

Specificity of the $S T_{a}$ effect. The taurine transporter in the intestine and in colon carcinoma cells also accepts $\beta$-alanine as a substrate (25-29). Therefore, to confirm the inhibitory effect of $\mathrm{ST}_{\mathrm{a}}$ on the activity of the taurine transporter, the influence of $\mathrm{ST}_{\mathrm{a}}$ on the uptake of $\beta$-alanine and on the uptake of substrates of unrelated transport systems was investigated. As shown in Table II, the uptake of $\beta$-alanine in Caco- 2 cells was also significantly inhibited by $\mathrm{ST}_{\mathrm{a}}$. However, under the same experimental conditions in which it caused inhibition of the taurine transporter (i.e., uptake of taurine and $\beta$-alanine), the toxin failed to elicit any change in the uptake of leucine, phenylalanine, glucose, or the dipeptide Gly-Sar. The uptake of proline, on the other hand, was inhibited by $\mathrm{ST}_{\mathrm{a}}$ to a significant extent.

Influence of $S T_{a}$ on the kinetic parameters of taurine uptake. In order to determine the effects of $\mathrm{ST}_{\mathrm{a}}$ on the kinetic parameters of taurine uptake, Caco-2 cells were treated for $30 \mathrm{~min}$ with or without $\mathrm{ST}_{\mathrm{a}}(50 \mathrm{nM})$ before the kinetic studies. The kinetic constants of taurine uptake were analyzed by determining the 10-min uptake rate of taurine over a concentration range of $0.1-4 \mu \mathrm{M}$. The uptake rate was hyperbolically related to the concentration of taurine and the relationship obeyed Michaelis- 


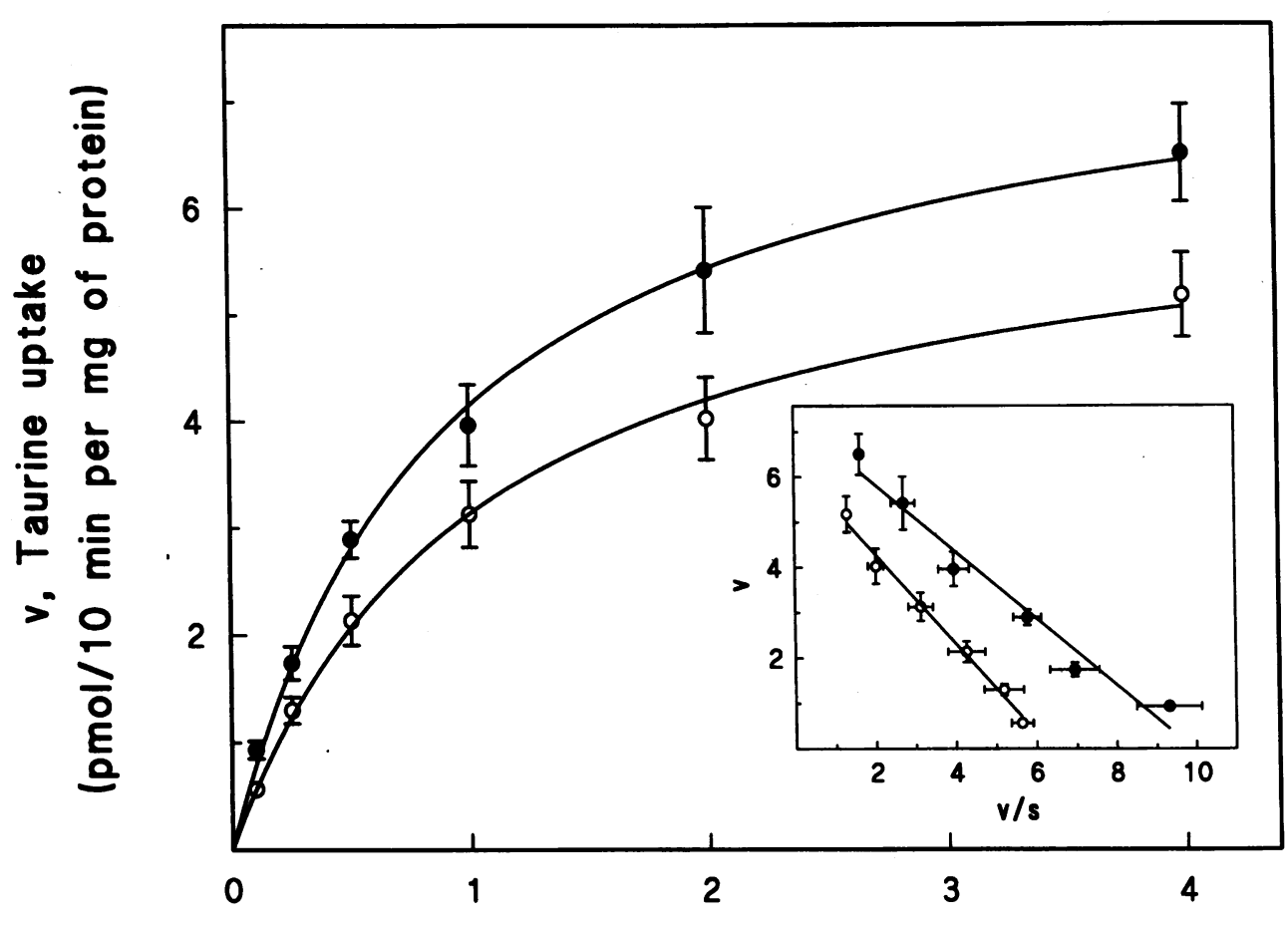

s, [Taurine] ( $\mu \mathrm{mol} / \mathrm{l})$
Figure 3. Influence of $\mathrm{ST}_{\mathrm{a}}$ on the kinetic parameters of taurine uptake in the Caco- 2 cell line. Confluent monolayer cultures of Caco- 2 cells were treated with (O) or without $(\bullet) \mathrm{ST}_{\mathrm{a}}(50 \mathrm{nM})$ for $30 \mathrm{~min}$. After treatment, uptake of taurine was measured over a concentration range of $0.1-4 \mu \mathrm{M}$ using a 10-min incubation. Concentration of $\left[{ }^{3} \mathrm{H}\right]$ taurine was maintained at $40 \mathrm{nM}$, and total concentration of taurine was altered by adding appropriate concentrations of unlabeled taurine. Uptake of radiolabel measured in the presence of $2 \mathrm{mM}$ unlabeled taurine was used to determine the nonmediated transport. This value was subtracted from total transport to calculate the mediated transport which was then used in data analysis. The results are given as taurine uptake $(v)$ versus taurine concentration $(s)$ and as Eadie-Hofstee plots (inset). $v$, uptake rate in pmol/ $10 \mathrm{~min}$ per $\mathrm{mg}$ of protein; $s$, taurine concentration in $\mu \mathrm{M}$. Values are means \pm SEM $(n=6)$.
Menten kinetics describing a single mediated process in control cells as well as in $\mathrm{ST}_{\mathrm{a}}$-treated cells (Fig. 3 ). The experimental data were transformed into a linear format by the Eadie-Hofstee method. Linear plots (uptake rate vs. uptake rate/taurine concentration) with regression coefficients of -0.982 (control) and $-0.995\left(\mathrm{ST}_{\mathrm{a}}\right)$, respectively, were obtained thus supporting the involvement of a single transport system (Fig. 3, inset). Moreover, the data show that $\mathrm{ST}_{\mathbf{a}}$ elicited alterations in the maximal velocity of taurine transport as well as in the affinity of the transporter for taurine. In control cells, the apparent Michaelis-

Table II. Effects of E. coli $S T_{a}$ on the Transport of Selected Substrates in Caco-2 Cells

\begin{tabular}{lccc}
\hline & \multicolumn{2}{c}{ Uptake } & \\
\cline { 2 - 3 } \multicolumn{1}{c}{ Substrate } & Control & ST $_{\mathbf{a}}$ & \% of control \\
\hline & \multicolumn{2}{c}{ pmolmin per } & \multicolumn{2}{c}{ mg of protein } \\
Taurine $(100 \mathrm{nM})$ & $0.13 \pm 0.01$ & $0.09 \pm 0.01$ & $69(P<0.01)$ \\
$\beta$-Alanine $(50 \mathrm{nM})$ & $0.047 \pm 0.003$ & $0.038 \pm 0.003$ & $81(P<0.05)$ \\
Leucine $(10 \mu \mathrm{M})$ & $493 \pm 12$ & $495 \pm 15$ & $100(\mathrm{NS})$ \\
Phenylalanine $(20 \mathrm{nM})$ & $1.81 \pm 0.12$ & $1.84 \pm 0.13$ & $102(\mathrm{NS})$ \\
Proline $(300 \mathrm{nM})$ & $0.69 \pm 0.01$ & $0.56 \pm 0.01$ & $81(P<0.01)$ \\
Glucose $(100 \mu \mathrm{M})$ & $2148 \pm 111$ & $2355 \pm 123$ & $110(\mathrm{NS})$ \\
Gly-Sar $(20 \mu \mathrm{M})$ & $32.7 \pm 2.7$ & $31.4 \pm 3.2$ & $96(\mathrm{NS})$ \\
& & & \\
\hline
\end{tabular}

Values represent means $\pm \operatorname{SEM}(n=5-7)$. After a 30-min treatment of monolayer cultures of Caco-2 cells with $\mathrm{ST}_{\mathrm{a}}(50 \mathrm{nM})$ at $37^{\circ} \mathrm{C}$, uptake of amino acids, glucose or Gly-Sar was measured using a 1-min incubation. For the amino acids and glucose, a $\mathrm{NaCl}$-containing buffer at $\mathrm{pH}$ 7.5 was used. Gly-Sar uptake was measured in a NaCl-containing buffer at $\mathrm{pH}$ 6.0.NS, not significant; $P$ values compared to respective controls.
Menten constant $\left(K_{t}\right)$ for the uptake process was $0.74 \pm 0.07$ $\mu \mathrm{M}$ and the maximal velocity $\left(\mathrm{V}_{\max }\right)$ was $7.31 \pm 0.40 \mathrm{pmol} / 10$ min per mg of protein. Treatment of the cells with $\mathrm{ST}_{\mathrm{a}}$ caused a significant decrease in the $\mathrm{V}_{\max }$ as well as in the affinity of the transport system $(P<0.02)$. In the treated cells, the $K_{t}$ was $0.98 \pm 0.05 \mu \mathrm{M}$ and $V_{\max }$ was $6.26 \pm 0.20 \mathrm{pmol} / 10 \mathrm{~min}$ per $\mathrm{mg}$ of protein.

Effect of $S T_{a}$ on intracellular cGMP and cAMP levels in Caco-2 and HT-29 cells. Measurement of intracellular concentrations of cGMP and cAMP revealed that $\mathrm{ST}_{\mathrm{a}}(50 \mathrm{nM})$ elicited a 21-fold increase of cGMP in Caco-2 cells after a 5-min treatment (Fig. 4). The cGMP levels in HT-29 cells which have been treated with $\mathrm{ST}_{\mathrm{a}}$ under identical conditions remained absolutely unaffected (Fig. $4 A$ ). There was no significant change in the intracellular levels of cAMP in both Caco-2 and HT-29 cells as a result of treatment with $\mathrm{ST}_{\mathrm{a}}$ (Fig. $4 \mathrm{~B}$ ).

Influence of cGMP analogues on taurine uptake. The apparent association between the inhibition of taurine uptake by $\mathrm{ST}_{\mathrm{a}}$ and guanylin and the increase in intracellular levels of cGMP following treatment with $\mathrm{ST}_{\mathrm{a}}$ in Caco- 2 cells indicates that this cyclic nucleotide is the likely second messenger mediating the inhibitory effect of $\mathrm{ST}_{\mathrm{a}}$ and guanylin. Therefore, we investigated the influence of cGMP analogues, 8-Br-cGMP and db-cGMP, on taurine uptake (Table III). With a 30-min incubation, dbcGMP (1 mM) caused significant inhibition of taurine uptake. This inhibition however was less than the inhibition observed with $\mathrm{ST}_{\mathrm{a}}$ or guanylin and did not increase when the incubation time was increased to $16 \mathrm{~h}$. Even though the inhibitory effect of 8-Br-cGMP failed to reach statistical significance, the trend to cause inhibition was readily apparent with this analog. Surprisingly, the taurine uptake in HT-29 cells was not affected by these cGMP analogues even when the treatment time was $16 \mathrm{~h}$ and the concentration of the cyclic nucleotides was as high as $5 \mathrm{mM}$. 
Table III. Effect of E. coli $S T_{a}$, Guanylin, and cGMP Analogues on Taurine Uptake in Caco-2 Cells

\begin{tabular}{lccc}
\hline & & \multicolumn{2}{c}{ Taurine uptake } \\
\cline { 3 - 4 } \multicolumn{1}{c}{ Compound } & $\begin{array}{c}\text { Treatment } \\
\text { time }\end{array}$ & $\begin{array}{c}\text { pmol/10 min per } \\
\text { mg of protein }\end{array}$ & \% control \\
\hline & $h$ & & \\
None & 0.5 & $0.66 \pm 0.04$ & 100 \\
$\mathrm{ST}_{\mathrm{a}}(50 \mathrm{nM})$ & 0.5 & $0.42 \pm 0.02$ & $64(P<0.001)$ \\
Guanylin $(5 \mu \mathrm{M})$ & 0.5 & $0.33 \pm 0.01$ & $50(P<0.001)$ \\
8-Br-cGMP $(1 \mathrm{mM})$ & 0.5 & $0.59 \pm 0.03$ & $89(\mathrm{NS})$ \\
db-cGMP $(1 \mathrm{mM})$ & 0.5 & $0.55 \pm 0.05$ & $83(P<0.05)$ \\
None & 16 & $0.49 \pm 0.03$ & 100 \\
8-Br-cGMP $(1 \mathrm{mM})$ & 16 & $0.43 \pm 0.04$ & $88(\mathrm{NS})$ \\
db-cGMP $(1 \mathrm{mM})$ & 16 & $0.39 \pm 0.03$ & $80(P<0.05)$ \\
& & & \\
\hline
\end{tabular}

Values are means $\pm \operatorname{SEM}(n=5-8)$. After treatment of monolayer cultures of Caco- 2 cells at $37^{\circ} \mathrm{C}$ for indicated time with the compounds shown, uptake of taurine $(40 \mathrm{nM})$ was measured using a 10 -min incubation in a $\mathrm{NaCl}$-containing uptake buffer at $\mathrm{pH}$ 7.5. $\mathrm{NS}$, not significant; $P$ values compared to respective controls.

Effect of protein kinase inhibitors on the inhibition of taurine uptake induced by $S T_{a}$. We then investigated the effect of protein kinase inhibitors on the $\mathrm{ST}_{\mathrm{a}}$-induced inhibition of taurine uptake. First, Caco- 2 cells were treated with or without $\mathrm{ST}_{\mathrm{a}}(50$ $\mathrm{nM})$ in the absence or presence of staurosporine (500 nM). Measurement of taurine uptake in these cells revealed that $\mathrm{ST}_{\mathrm{a}}$ inhibited taurine uptake by $35 \%$, whereas staurosporine increased it by $100 \%$ (Fig. 5). When cells were treated with $\mathrm{ST}_{\mathrm{a}}$ and staurosporine together, taurine uptake was the same as that in cells treated with staurosporine alone. This shows that staurosporine itself increases the taurine uptake and that it blocks the effect of $\mathrm{ST}_{\mathrm{a}}$ completely. However, staurosporine is a relatively nonselective protein kinase inhibitor that might inhibit protein kinase $A$, protein kinase $G$, and protein kinase $C$ under the experimental conditions described. In order to identify the protein kinase involved in the mediation of the $\mathrm{ST}_{\mathrm{a}}$ effect, we tested a selective protein kinase A inhibitor ( $\mathrm{H}-89$ ), a selective protein kinase G inhibitor (KT5823) and a selective protein kinase C inhibitor (chelerythrine) for their ability to block the effect of $\mathrm{ST}_{\mathrm{a}}$ (Fig. 5). Treatment of Caco- 2 cells with $\mathrm{H}-89$ alone for 2 $\mathrm{h}$ caused a significant inhibition of taurine uptake $(33 \%$ at a concentration of $30 \mu \mathrm{M}) . \mathrm{ST}_{\mathrm{a}}$, which inhibited taurine uptake by $33 \%$ when incubated alone with the cells, failed to inhibit the uptake if $\mathrm{H}-89$ was present during the treatment. Thus, the selective protein kinase A inhibitor was able to block completely the inhibitory effect of $\mathrm{ST}_{\mathrm{a}}$. Treatment of Caco-2 cells with the protein kinase $\mathrm{G}$ inhibitor KT5823 also caused a significant inhibition of taurine uptake (32\% at a concentration of $15 \mu \mathrm{M}) . \mathrm{ST}_{\mathrm{a}}$ inhibited taurine uptake by $39 \%$ when incubated alone with the cells but it also inhibited the uptake (31\%) when KT5823 was present before and during the treatment. Thus, the selective protein kinase $\mathrm{G}$ inhibitor was unable to block the inhibitory effect of $\mathrm{ST}_{\mathrm{a}}$ on taurine uptake. The experiments with the protein kinase $\mathrm{C}$ inhibitor chelerythrine also showed a similar pattern. Chelerythrine by itself $(15 \mu \mathrm{M})$ inhibited the taurine uptake by $30 \%$. ST $\mathrm{a}$ inhibited the uptake of taurine by $34 \%$ in these experiments. However, a similar inhibition (40\%) by $\mathrm{ST}_{\mathrm{a}}$ was observed when the cells were cotreated with chelerythrine and $\mathrm{ST}_{\mathrm{a}}$. These results indicate that protein kinase $\mathrm{G}$ as well as protein kinase $\mathrm{C}$ are not involved in the inhibition of taurine uptake induced by $\mathrm{ST}_{\mathrm{a}}$ and that protein kinase $\mathrm{A}$ mediates the $\mathrm{ST}_{\mathrm{a}}$ effect most likely by cross-activation of the kinase by increased levels of cGMP. Interestingly, treatment of the cells with the protein kinase inhibitors alone had significant effects on taurine uptake. The stimulation caused by staurosporine can be explained, at least in part, by its ability to block the inhibitory influence of protein kinase $C(30)$ and protein kinase A (see below) on the taurine transporter activity. The reasons for the observed inhibition of taurine uptake by other protein kinase inhibitors ( $\mathrm{H}-89$, chelerythrine, and KT5823) are not known.
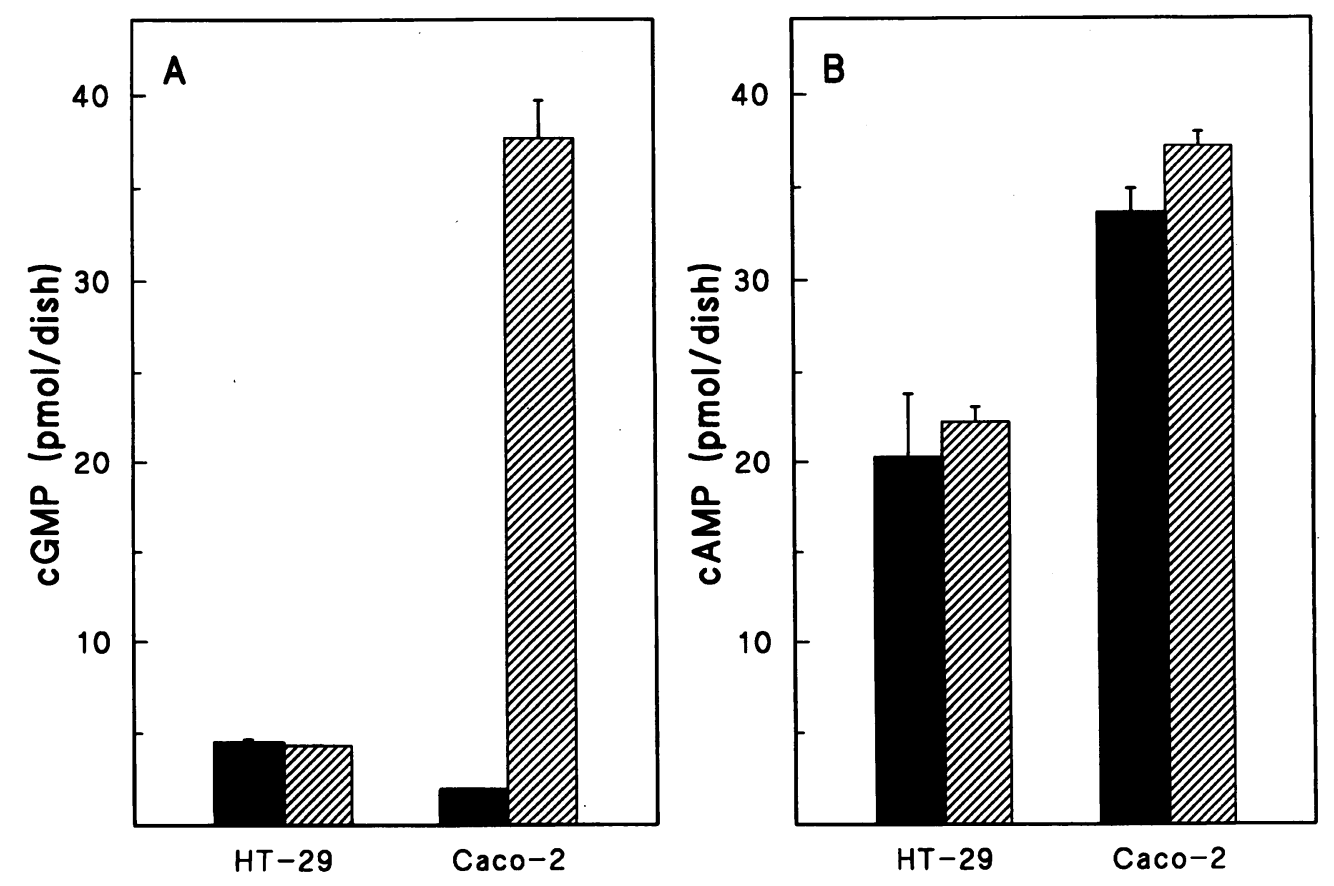

Figure 4. Effects of $\mathrm{ST}_{\mathrm{a}}$ on intracellular cGMP and cAMP concentrations in HT-29 and Caco-2 cell lines. Confluent monolayer cultures of both cell lines cultured in 35-mm dishes were preincubated for $15 \mathrm{~min}$ in a $\mathrm{NaCl}$-containing buffer ( $\mathrm{pH} 7.5)$ in the presence of $1 \mathrm{mM}$ IBMX followed by treatment with (striped bars) or without $\mathrm{ST}_{\mathrm{a}}$ (filled bars) for $5 \mathrm{~min}$ in the presence of IBMX (1 mM). The concentration of $\mathrm{ST}_{\mathrm{a}}$ was 50 nM. After treatment, cells were lysed in $0.1 \mathrm{~N} \mathrm{HCl}$. The concentrations of CGMP $(A)$ and cAMP $(B)$ were measured in these samples. Values are means \pm SEM $(n=3$, measured in duplicates $)$. 


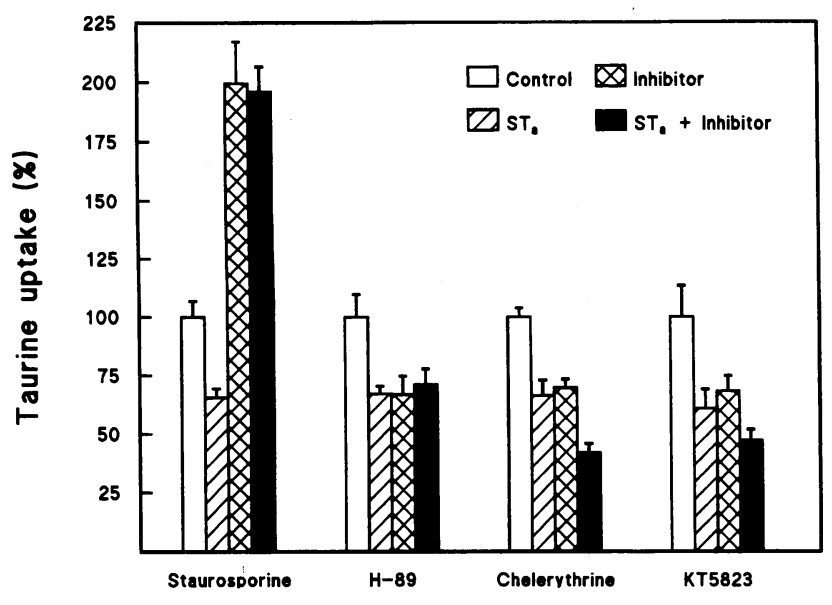

Figure 5. Influence of protein kinase inhibitors on the inhibitory effect of $\mathrm{ST}_{\mathrm{a}}$. Confluent monolayer cultures of Caco- 2 cells were treated in medium for $1 \mathrm{~h}$ with or without $\mathrm{ST}_{\mathrm{a}}(50 \mathrm{nM})$. The inhibitors except chelerythrine were added $1 \mathrm{~h}$ before $\mathrm{ST}_{\mathrm{a}}$. The media contained either no compound (vehicles only, control) or $\mathrm{ST}_{\mathrm{a}}$ (plus the vehicle of the test compound) or the inhibitor (plus water as the vehicle of the toxin) or $\mathrm{ST}_{\mathrm{a}}$ and the inhibitor in their respective vehicles. Staurosporine (500 $\mathrm{nM}$ in water) for $2 \mathrm{~h}(n=4-5) ; \mathrm{H}-89$ (30 $\mu \mathrm{M}$ in DMSO) for $2 \mathrm{~h}$ $(n=4-5)$, KT5823 ( $10 \mu \mathrm{M}$ in DMSO) for $2 \mathrm{~h}(n=4)$, chelerythrine ( $15 \mu \mathrm{M}$ in DMSO) for $1 \mathrm{~h}(n=5)$. The final DMSO concentration during treatment varied within the range of $0.1-0.4 \%$ depending on the experiment. Following the treatment, uptake of taurine $(40 \mathrm{nM})$ was measured for $10 \mathrm{~min}$ in uptake buffer at $\mathrm{pH}$ 7.5. Values (percent of control uptake) are means \pm SEM.

Influence of cholera toxin on taurine uptake in Caco-2 cells. We then investigated the effect of cholera toxin, an agent known to increase intracellular cAMP levels, on taurine uptake in Caco2 cells. Treatment of the cells with the toxin $(100 \mathrm{ng} / \mathrm{ml})$ for $4 \mathrm{~h}$ caused $51 \%$ inhibition of taurine uptake (Fig. $6 \mathrm{~A}$ ). This inhibition was accompanied by a 118 -fold increase in the intracellular levels of cAMP (Fig. $6 \mathrm{~B}$ ). Cholera toxin treatment had only a small effect on cGMP levels. These data clearly show that activation of protein kinase $A$ leads to inhibition of taurine uptake in Caco-2 cells.

Influence of $S T_{a}$ on steady state levels of taurine transporter mRNA transcripts in Caco-2 cells. To determine whether the $\mathrm{ST}_{\mathrm{a}}$-induced inhibition of taurine uptake in Caco-2 cells is associated with any change in the levels of the taurine transporter mRNA, Northern analysis was carried out. The presence of a major hybridizing mRNA species, $6.9 \mathrm{~kb}$ in size, was evident in control cells as well as in $\mathrm{ST}_{\mathrm{a}}$-treated cells, but $\mathrm{ST}_{\mathrm{a}}$ treatment had no effect on the levels of this transcript (data not shown). Thus, the inhibition of taurine uptake induced by $\mathrm{ST}_{\mathrm{a}}$ in Caco2 cells is not accompanied by any change in the steady state levels of the taurine transporter mRNA. These studies were done using the human placental taurine transporter cDNA as the probe. There is evidence that a mRNA transcript with an identical coding region is expressed in Caco-2 cells and in human small intestine (unpublished data). It is not known at this time whether this transcript codes for the brush border or the basolateral taurine transporter. However, it should be noted that the functional characteristics of the cloned placental taurine transporter are very similar to those of the taurine transporter described in intestinal brush border membrane vesicles, making it highly possible that the $6.9-\mathrm{kb}$ transcript identified by the placental probe is related to the apical taurine transporter in Caco- 2 cells.
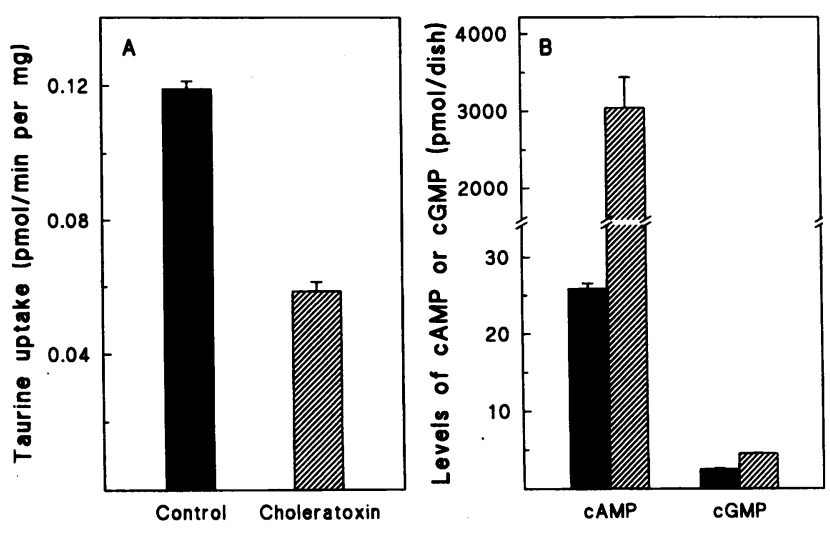

Figure 6. Effect of cholera toxin-treatment on taurine uptake and on intracellular cAMP and cGMP concentrations in Caco-2 cells. $(A)$ Confluent monolayer cultures of Caco- 2 cells were treated for $4 \mathrm{~h}$ with or without cholera toxin $(100 \mathrm{ng} / \mathrm{ml})$ in cell culture medium. Taurine uptake was measured at $\mathrm{pH} 7.5$ using a 1-min incubation time at a taurine concentration of $100 \mathrm{nM}(n=5)$. (B) Monolayers were treated for $4 \mathrm{~h}$ in a $\mathrm{NaCl}$-containing buffer ( $\mathrm{pH} 7.5$ ) with (striped bars) or without cholera toxin ( $100 \mathrm{ng} / \mathrm{ml}$, filled bars) in the presence of $1 \mathrm{mM}$ IBMX. After treatment, cells were lysed in $0.1 \mathrm{~N} \mathrm{HCl}$. The concentrations of cAMP and cGMP were measured in these samples. Values are means $\pm \operatorname{SEM}$ ( $n=3$, measured in duplicates).

Effect of $S T_{a}$ on taurine uptake in Caco-2 cells cultured on permeable filters. Caco- 2 cells grown on permeable cell culture inserts for 14 to $17 \mathrm{~d}$ form a differentiated monolayer. The integrity of the cell monolayer was confirmed microscopically, by measuring the transepithelial resistance and by measuring the transepithelial flux of inulin. Under the conditions described, the transepithelial resistance of the Caco- 2 cell monolayers at the time of the uptake experiments ( 14 to $17 \mathrm{~d}$ of culture) was $639 \pm 11 \Omega \times \mathrm{cm}^{2}\left(n=18\right.$, range 554 to $\left.719 \Omega \times \mathrm{cm}^{2}\right)$. The transepithelial $\left[{ }^{14} \mathrm{C}\right]$ inulin flux through the Caco-2 cell monolayers was less than $0.1 \% / \mathrm{h}$. We studied taurine uptake from the apical as well as from the basolateral side. As shown in Fig. 7, the basolateral uptake was found to be $35 \%$ lower than that from the apical side. To address the question of polarity, i.e., from which side the toxin elicits its effect, we treated the Caco-2 cell monolayers either in the apical or in the basolateral medium with $\mathrm{ST}_{\mathrm{a}}(200 \mathrm{nM})$ for $1 \mathrm{~h}$. Treatment with $\mathrm{ST}_{\mathrm{a}}$ at the apical side inhibited the apical taurine uptake by $31 \%(P$ $=0.0014)$. The basolateral taurine uptake was not affected by $\mathrm{ST}_{\mathrm{a}}$. Moreover, $\mathrm{ST}_{\mathrm{a}}$ elicits its effect mainly from the apical side. When treatment with $\mathrm{ST}_{\mathrm{a}}$ was done on the basolateral side, there was only a small $(14 \%)$ but statistically insignificant $(P$ $=0.06$ ) inhibition of the apical taurine uptake.

\section{Discussion}

In the present investigation, we focused on the role of cGMP in the modulation of taurine transport activity in the colon carcinoma cell lines, Caco-2 and HT-29. This cyclic nucleotide has been shown to be one of the three primary agents, the other two being cAMP and $\mathrm{Ca}^{2+}$, which regulate absorption/secretion of electrolytes in the intestine (39). The results presented here show that $\mathrm{ST}_{\mathrm{a}}$ causes a significant decrease in taurine transport activity in Caco- 2 cells but not in HT-29 cells. The inhibitory effect of $\mathrm{ST}_{\mathrm{a}}$ in Caco-2 cells is accompanied by an increase in the intracellular levels of cGMP. The inability of the toxin 


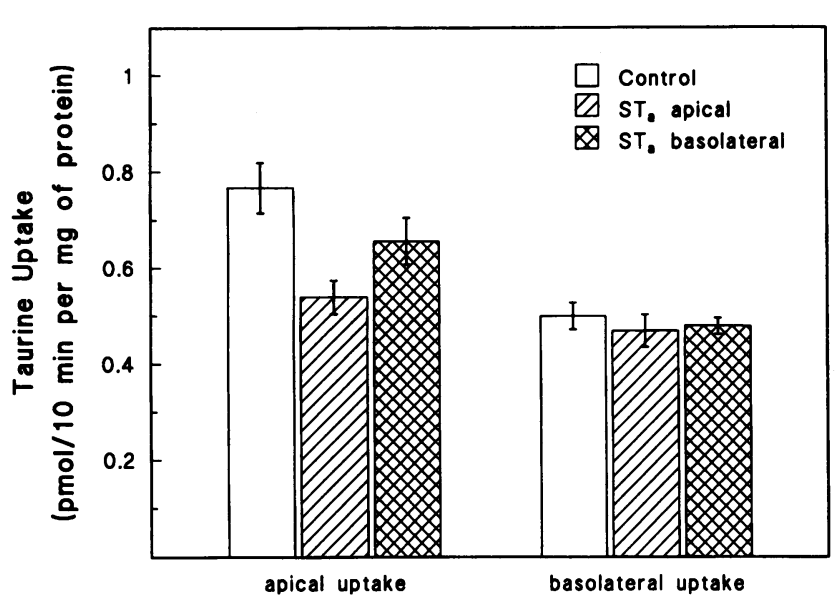

Figure 7. Effect of $\mathrm{ST}_{\mathrm{a}}$ on taurine uptake in Caco-2 cells cultured on permeable membrane filters. Confluent monolayer cultures of Caco-2 cells grown on filters for 14 to $17 \mathrm{~d}$ were treated in medium for $1 \mathrm{~h}$ with or without $\mathrm{ST}_{\mathrm{a}}(200 \mathrm{nM})$. Following the treatment, monolayers were washed and uptake buffer containing taurine $(60 \mathrm{nM})$ was added either to the apical or to the basolateral compartment of the filter inserts. Uptake was measured using a 10-min incubation time at room temperature. Values are means \pm SEM. $n=9-11$ (apical uptake) or 7 (basolateral uptake).

to inhibit taurine transport in HT-29 cells is explained by the observation that the toxin failed to alter cGMP levels in this cell line. The presence of the membrane-bound guanylate cyclase, the cellular receptor for the enterotoxin, has been demonstrated in Caco-2 cells (5). The HT-29 cells apparently lack the membrane-bound guanylate cyclase that is activatable by $\mathrm{ST}_{\mathrm{a}}$. However, since cGMP analogues were unable to inhibit the taurine uptake in these cells, it appears that some other cellular components involved in the biological effects of cGMP are also altered in these cells.

Since $\mathrm{ST}_{\mathrm{a}}$ failed to affect taurine transport activity in HT29 cells, subsequent experiments to characterize the influence of $\mathrm{ST}_{\mathrm{a}}$ and cGMP on the activity of the taurine transporter were carried out with Caco- 2 cells. The effect of $\mathrm{ST}_{\mathrm{a}}$ on taurine uptake in Caco- 2 cells is time-dependent, reaching a maximum at $30 \mathrm{~min}$. Dose-response relationship indicates that the concentration of the toxin necessary to elicit $50 \%$ of the maximal effect is $\sim 20 \mathrm{nM}$. The experiments performed on filters show that $\mathrm{ST}_{\mathrm{a}}$ elicits its effect mainly from the apical side. It remains to be clarified why the basolateral taurine uptake is not affected by treatment with $\mathrm{ST}_{\mathrm{a}}$. One possibility is that the carrier proteins in the luminal and basolateral membranes are different. Evidence for the existence of distinct taurine carriers at the apical and basolateral membranes which differ in functional characteristics has been provided by studies with cultured renal cell lines (40) as well as with isolated membrane vesicles from the kidney (41).

The inhibition of taurine uptake is not a nonspecific effect because under identical conditions uptake of several other nutrients remains unaffected. Kinetic analysis reveals that the $\mathrm{ST}_{\mathrm{a}}$ induced inhibition is associated with a decrease in the $\mathrm{V}_{\max }$ and also with an increase in the $K_{t}$. There is however no change in the steady state levels of the taurine transporter mRNA transcripts. The changes seen in the kinetic parameters of the taurine transport activity as a result of treatment with $\mathrm{ST}_{\mathrm{a}}$ thus appear to be due to posttranscriptional events. Intracellular cGMP is involved in the initiation of these events because the $\mathrm{ST}_{\mathrm{a}}$ effect is accompanied by an increase in cGMP levels. In HT-29 cells where there is no increase in cGMP levels as a result of treatment with $\mathrm{ST}_{\mathrm{a}}$, the toxin has no effect on taurine uptake. These data clearly indicate a role for cGMP in the $\mathrm{ST}_{\mathrm{a}}$-induced inhibition of the taurine transport activity in Caco- 2 cells.

This study also presents evidence for the regulation of the taurine transporter in Caco- 2 cells by the endogenous peptide guanylin. The influence of guanylin on the taurine transporter is the same as that of $\mathrm{ST}_{\mathrm{a}}$. Guanylin is known to be an endogenous agonist for the membrane-bound guanylate cyclase, and therefore it is most likely that the effect of guanylin on the taurine transporter activity in Caco-2 cells is also mediated by cGMP. This constitutes the first report on the regulation of an organic solute transport system by this endogenous peptide. These studies raise the possibility that guanylin may play a significant role in the regulation of intestinal transport of not only ions but also other nutrients as well.

The exact mechanisms by which cGMP inhibits the activity of the taurine transporter in Caco- 2 cells remains speculative at this time. cGMP could activate protein kinase $G$ that might phosphorylate the transporter protein resulting in the inhibition of its catalytic activity. cGMP might also activate protein kinase A by directly interacting with the enzyme. Even though the affinity of protein kinase A for cGMP is much lower than for cAMP, high levels of cGMP might compensate for this low affinity and cause activation of protein kinase $A$ to a significant extent. There are several lines of evidence in support of this hypothesis. Only staurosporine, which is a nonspecific inhibitor of protein kinases, and $\mathrm{H}-89$, which is a specific inhibitor of protein kinase $\mathrm{A}$, are able to block the $\mathrm{ST}_{\mathrm{a}}$ effect. The membrane permeable cGMP analogues, which are poor activators of protein kinase $\mathrm{A}$, are significantly less effective than $\mathrm{ST}_{\mathrm{a}}$ or guanylin. In addition, elevation of cAMP levels by treatment with cholera toxin mimics the effects of $\mathrm{ST}_{\mathrm{a}}$ or guanylin. Taken together, these results strongly suggest that protein kinase A mediates the $\mathrm{ST}_{\mathrm{a}}$ - or guanylin-induced inhibition of the taurine transporter activity in these cells.

In conclusion, the present study shows that the catalytic function of the taurine transporter in Caco- 2 cells is regulated by cGMP-dependent cellular processes via protein kinase $\mathrm{A}$. The levels of cGMP in these cells are elevated by $\mathrm{ST}_{\mathrm{a}}$, an enterotoxin produced by certain strains of $E$. coli or by guanylin, an endogenous peptide. These results suggest that infection with enterotoxigenic $E$. coli may lead to impaired intestinal absorption of taurine. Since the intestinal uptake of taurine is coupled to sodium uptake $\left(\mathrm{Na}^{+} /\right.$taurine coupling ratio for the uptake process is 2 or 3 ), the inhibition of the activity of the taurine transporter might represent at least one of the mechanisms by which $\mathrm{ST}_{\mathrm{a}}$ leads to defective intestinal sodium absorption. It has to be noted however that the quantitative significance of the contribution of the $\mathrm{Na}^{+}$-taurine cotransport process to the intestinal absorption of $\mathrm{Na}^{+}$varies widely among individuals depending upon the diet. While some dietary constituents (e.g., vegetables) contain very little taurine, some others (e.g., meat, fish) may contain as high as $50 \mathrm{mM}$ taurine. The present study also shows that cholera toxin, a diarrheagenic factor produced by Vibrio cholerae, impairs taurine uptake in Caco-2 cells, strongly implying that intestinal absorption of taurine may be impaired in cholera. Implications of these findings to the taurine status of infants and young children, an age group in which the prevalence of infection with enterotoxigenic $E$. coli and $V$. cholerae is high, are readily apparent because of the critical role of intestinal 
absorption in the maintenance of taurine nutrition in this population.

\section{Acknowledgments}

The authors thank Dr. R. T. Borchardt, Dr. G. M. Pauletti, and Dr. K. Hillgren (Department of Pharmaceutical Chemistry, University of Kansas) for helpful discussions and for providing Caco-2 cells. The excellent secretarial assistance of I. O. Thomas is gratefully acknowledged.

This work was supported by National Institutes of Health grants DK 28389 (F. H. Leibach) and HD 24451 (V. Ganapathy), by a fellowship from Deutsche Forschungsgemeinschaft to $\mathrm{M}$. Brandsch ( $\mathrm{Br}$ 1317/1-1 and 1-2) and by a grant from Taisho Pharmaceutical Company, Japan.

\section{References}

1. Levine, M. M. 1987. Escherichia coli that causes diarrhea: enterotoxigenic, enteropathogenic, enteroinvasive, enterohemorrhagic, and enteroadherent. $\mathbf{J}$. Infect. Dis. 155:377-389.

2. Farthing, M. J. G. 1994. Travellers' diarrhoea. Gut. 35:1-4.

3. Giannella, R. A., M. Luttrell, and M. Thompson. 1983. Binding of Escherichia coli heat-stable enterotoxin to receptors on rat intestinal cells. Am. J. Physiol. 245:G492-G498.

4. Guarino, A., M. B. Cohen, G. Overmann, M. R. Thompson, and R. A. Giannella. 1987. Binding of $E$. coli heat-stable enterotoxin to rat intestinal brush borders and to basolateral membranes. Dig. Dis. Sci. 32:1017-1026.

5. Cohen, M. B., N. J. Jensen, J. A. Hawkins, E. A. Mann, M. R. Thompson, M. J. Lentze, and R. A. Giannella. 1993. Receptors for Escherichia coli heat stable enterotoxin in human intestine and in a human intestinal cell line (Caco2). J. Cell. Physiol. 156:138-144.

6. Field, M., L. H. Graf, W. J. Laird, and P. S. Smith. 1978. Heat-stable enterotoxin of Escherichia coli: in vitro effects on guanylate cyclase activity, cyclic GMP concentration, and ion transport in the small intestine. Proc. Natl. Acad. Sci. USA. 75:2800-2804.

7. Schulz, S., C. K. Green, P. S. T. Yuen, and D. L. Garbers. 1990. Guanylyl cyclase is a heat-stable enterotoxin receptor. Cell. 63:941-948.

8. Wong, S. K.-F., and D. L. Garbers. 1992. Receptor guanylyl cyclases. J. Clin. Invest. 90:299-305.

9. Huott, P. A., W. Liu, J. A. McRoberts, R. A. Giannella, and K. Dharmsathaphorn. 1988. Mechanism of action of Escherichia coli heat stable enterotoxin in a human colonic cell line. J. Clin. Invest. 82:514-523.

10. Forte, L. R., P. K. Thorne, S. L. Eber, W. J. Krause, R. H. Freeman, S. H. Francis, and J. D. Corbin. 1992. Stimulation of intestinal $\mathrm{Cl}^{-}$transport by heatstable enterotoxin: activation of cAMP-dependent protein kinase by cGMP. Am J. Physiol. 263:C607-C615.

11. Tien, X. Y., T. A. Brasitus, M. A. Kaetzel, J. R. Dedman, and D. J. Nelson. 1994. Activation of the cystic fibrosis transmembrane conductance regulator by cGMP in the human colonic cancer cell line, Caco-2. J. Biol. Chem. 269:51-54.

12. Chao, A. C., F. J. de Sauvage, Y. J. Dong, J. A. Wagner, D. V. Goeddel, and P. Gardner. 1994. Activation of intestinal CFTR $\mathrm{Cl}^{-}$channel by heat-stable enterotoxin and guanylin via cAMP-dependent protein kinase. EMBO (Eur. Mol. Biol. Organ.) J. 13:1065-1072.

13. Guandalini, S., M. C. Rao, P. L. Smith, and M. Field. 1982. cGMP modulation of ileal ion transport: in vitro effects of Escherichia coli heat-stable enterotoxin. Am. J. Physiol. 243:G36-G41.

14. Guarino, A. L., Tarallo, R. B. Canani, A. Nocerino, M. Iafusco, F. Raimondi, and A. Rubino. 1992. Comparative effects of atrial natriuretic peptide and E. coli heat-stable toxin on rat intestinal transport. J. Pediatr. Gastroenterol. Nutr. 15:105-111

15. Currie, M. G., K. F. Fok, J. Kato, R. J. Moore, F. K. Hamra, K. L. Duffin, and C. E. Smith. 1992. Guanylin: an endogenous activator of intestinal guanylate cyclase. Proc. Natl. Acad. Sci. USA. 89:947-951.

16. Wiegand, R. C., J. Kato, M. D. Huang, K. F. Fok, J. F. Kachur, and M. G. Currie. 1992. Human guanylin: cDNA isolation, structure, and activity. FEBS (Fed. Eur. Biochem. Soc.) Lett. 311:150-154.

17. de Sauvage, F. J., S. Keshav, W. J. Kuang, N. Gillett, W. Henzel, and D. V. Goeddel. 1992. Precursor structure, expression, and tissue distribution of human guanylin. Proc. Natl. Acad. Sci. USA. 89:9089-9093.
18. Caprick, B. W., and J. Gariepy. 1993. The Escherichia coli heat-stable enterotoxin is a long-lived superagonist of guanylin. Infect. Immun. 61:47104715.

19. Forte, L. R., S. L. Eber, J. T. Turner, R. H. Freeman, K. F. Fok, and M. G. Currie. 1993. Guanylin stimulation of $\mathrm{Cl}^{-}$secretion in human intestinal $\mathrm{T}_{84}$ cells via cyclic guanosine monophosphate. J. Clin. Invest. 91:2423-2428.

20. Hamra, F. K., L. R. Forte, S. L. Eber, N. V. Pidhorodeckyj, W. J. Krause, R. H. Freeman, D. T. Chin, J. A. Tompkins, K. F. Fok, C. E. Smith et al. 1993. Uroguanylin: structure and activity of a second endogenous peptide that stimulates intestinal guanylate cyclase. Proc. Natl. Acad Sci. USA. 90:10464-10468.

21. Huxtable, R. J. 1992. Physiological actions of taurine. Physiol. Rev. 72:101-163.

22. Sturman, J. A. 1993. Taurine in development. Physiol. Rev. 73:119-147.

23. Ganapathy, V., M. Brandsch, and F. H. Leibach. 1994. Intestinal transport of amino acids and peptides. In Physiology of the Gastrointestinal Tract. Third Edition. L. R. Johnson, editor. Raven Press Ltd., NY. 1773-1794.

24. Moyer, M. S., A. L. Goodrich, M. M. Rolfes, and F. J. Suchy. 1988. Ontogenesis of intestinal taurine transport: evidence for a $\beta$-carrier in developing rat jejunum. Am. J. Physiol. 254:G870-G877.

25. Barnard, J. A., S. Thaxter, K. Kikuchi, and F. K. Ghishan. 1988. Taurine transport by rat intestine. Am. J. Physiol. 254:G334-G338.

26. Miyamoto, Y., C. Tiruppathi, V. Ganapathy, and F. H. Leibach. 1989. Active transport of taurine in rabbit jejunal brush border membrane vesicles. Am. J. Physiol. 257:G65-G72.

27. Miyamoto, Y., H. Nakamura, T. Hoshi, V. Ganapathy, and F. H. Leibach 1990. Uphill transport of $\beta$-alanine in intestinal brush border membrane vesicles. Am. J. Physiol. 259:G372-G379.

28. Miyamoto, Y., P. Kulanthaivel, V. Ganapathy, G. M. Whitford, and F. H. Leibach. 1990. Calcium-induced inhibition of taurine transport in brush border membrane vesicles from rabbit intestine. Biochim. Biophys. Acta. 1030:189-194.

29. Tiruppathi, C., M. Brandsch, Y. Miyamoto, V. Ganapathy, and F. H. Leibach. 1992. Constitutive expression of the taurine transporter in a human colon carcinoma cell line. Am. J. Physiol. 263:G625-G631.

30. Brandsch, M., Y. Miyamoto, V. Ganapathy, and F. H. Leibach. 1993. Regulation of taurine transport in human colon carcinoma cells lines (HT-29 and Caco-2) by protein kinase C. Am. J. Physiol. 264:G939-G946.

31. Hidalgo, I. J., T. J. Raub, and R. T. Borchardt. 1989. Characterization of the human colon carcinoma cell line (Caco-2) as a model for intestinal epithelial permeability. Gastroenterology. 96:736-749.

32. Brandsch, M., Y. Miyamoto, V. Ganapathy, and F. H. Leibach. 1994 Expression and protein kinase $\mathrm{C}$-dependent regulation of peptide $/ \mathrm{H}^{+}$cotransport system in the Caco-2 human colon carcinoma cell line. Biochem. J. 299:253260.

33. Kulanthaivel, P., D. R. Cool, S. Ramamoorthy, V. B. Mahesh, F. H. Leibach, and V. Ganapathy. 1991. Transport of taurine and its regulation by protein kinase $\mathrm{C}$ in the JAR human placental choriocarcinoma cell line. Biochem. J. 277:53-58.

34. Marczin, N., U. S. Ryan, and J. D. Catravas. 1992. Effects of oxidant stress on endothelium-derived relaxing factor- and nitrovasodilator-induced cGMP accumulation in vascular cells in culture. Circ. Res. 70:326-340.

35. Ramamoorthy, S., D. R. Cool, V. B. Mahesh, F. H. Leibach, H. E. Melikian, R. D. Blakely, and V. Ganapathy. 1993. Regulation of the human serotonin transporter. Cholera toxin-induced stimulation of serotonin uptake in human placental choriocarcinoma cells is accompanied by increased serotonin transporter mRNA levels and serotonin transporter-specific ligand binding. J. Biol. Chem 268:21626-21631.

36. Ramamoorthy, S., F. H. Leibach, V. B. Mahesh, H. Han, T. Yang-Feng, R. D. Blakely, and V. Ganapathy. 1994. Functional characterization and chromosomal localization of a cloned taurine transporter from human placenta. Biochem. J. 300:893-900.

37. Blais, A., P. Bissonnette, and A. Berteloot. 1987. Common characteristics for $\mathrm{Na}^{+}$-dependent sugar transport in Caco-2 cells and human fetal colon. $J$. Membr. Biol. 99:113-125.

38. Burnham, D. B., and J. D. Fondacaro. 1989. Secretagogue-induced protein phosphorylation and chloride transport in Caco-2 cells. Am. J. Physiol. 256:G808G816.

39. Donowitz, M., and M. J. Welsh. 1987. Regulation of mammalian small intestinal electrolyte secretion. In Physiology of the Gastrointestinal Tract. Second edition. L. R. Johnson, editor. Raven Press Ltd., NY. 1351-1388.

40. Jones, D. P., L. A. Miller, and R. W. Chesney. 1993. Polarity of taurine ransport in cultured renal epithelial cell lines: LLC-PK $_{1}$ and MDCK. Am. J. Physiol. 265:F137-F145.

41. Benyajati, S., and S. M. Bay. 1994. Basolateral taurine transport system in reptilian renal cells. Am. J. Physiol. 266:F439-F449. 